\title{
Effect Of Planning On Performance Of County Governments In Kenya
}

\author{
Wahinya Grace Njeri \\ Jomo Kenyatta University of Agriculture and Technology (JKUAT), \\ Nairobi Kenya \\ Prof. Mukulu Elegwa \\ Jomo Kenyatta University of Agriculture and Technology (JKUAT), \\ Nairobi Kenya \\ Prof. Waititu Anthony \\ Jomo Kenyatta University of Agriculture and Technology (JKUAT), \\ Nairobi Kenya
}

\begin{abstract}
The purpose of this study was to determine the effect of planning on performance of county governments in Kenya. Questionnaire was used to collect data from seven counties in Kenya drawn from 47 county governments in Kenya. Two tools of analysis were adopted by this study namely: correlation analysis and regression analysis. The correlation analysis was used to show the positive correlation between the predictor and response variables while regression analysis was used to explain the relationship between the predictor and response variables. R-squared was used to provide the strength of the relationship between the model and the response variable and determine its goodness fit. While $F$ statistics was used to test the significance of the regression model. The study adopted correlational research design. The findings revealed that performance of county government is significantly influenced by planning. From the findings, the study concludes that the county governments should enhance on further improvement in the area of planning in order to enhance the benefit of planning on performance of county governance.
\end{abstract}

Key Words: Planning, Performance, County Government

\section{INTRODUCTION}

Strategic management provides overall direction that involves formulation and implementation of the organizational goals. This involves specifying the organizational objectives and from them, develops plans and policies to enable the organization achieve its set objectives as well as allocate resources to implement the plans. This is done through the consideration of resources and assessment of internal and external environments in which the organizations functions. Strategic management incorporates all management hitches that may arise soon the strategic plans are developed, when other management process functions must be performed. Strategic management vividly states that a plan is incomplete by the time it has been implemented and evaluated and hence managers in strategic management are called to consider daily operations in the context of a longer period as well as change of external environment. In order to support new initiatives that spring from certain changes in the organizational environment, organizational structure and other fundamentals of management have to be adequate (24). 
Planning refers to the act of developing broad plans of action necessary to attain the organization's goals as well as objectives, establishing and periodically confirming the organization's mission and its context for management. This means, allocating resources on a basis consistent with strategic directions and goals and objectives, and managing the various lines of business and deploying the organization mission and strategy that is, articulating and communicating it, as well as developing action plans at lower levels that are supportive of those at the enterprise level (18). Planning is a core variable as it gives organizations the direction they should take, what they wish to do in totality, where they are and where they wish to go. Strategic planning is the procedure of developing tactics, strategies, and organization objectives to achieve the mission of the organization. The organization produces short and long-term objectives by means of the mission statement. Objectives in the case of public sector may include, revenue collection goals and customer as well as citizen satisfaction reckonings. The next step in planning is developing strategies to help the organization in the accomplishment of the objectives. For instance, better training and monitoring of feedback scores are strategies that held in achievement of higher customer satisfaction. This is followed by development of actionable steps or tactics. A tactic tied to the customer satisfaction goal and the training strategy is hiring an external training consultant for a chain of service training sessions (27).

\section{STATEMENT OF THE PROBLEM}

Strategic Management Practices: Planning, Governance, Quality Management and Innovation are central organization performance. Planning ensures that a calculated, well-organized effort to produce essential decisions and engagements that shape and monitor what it does and why it does it (6). County governments are vital vehicles for grassroots social-economic development in Kenya. Strategic management practices are therefore, important to county government's prudent management of resources for optimal performance. However, county governments face a number of challenges in executing their constitutional mandated functions. These challenges are as a result of poor strategic management practices. Studies by Ondigi (19), Korir (14) and Muli (17) indicate that poor planning in county governments has resulted to high levels of corruption. Planning within the county government in Kenya is wanting as envisioned by poor performance. It is, therefore, important that the County Government should improve their planning to enhance their performance. The challenges faced by the county governments as evidenced by the research can be attributed to poor implementation of planning. This study sought to establish the effects of planning on the performance of county government in Kenya and thus fill the knowledge gap.

The study sought to answer a key question:

\section{RESEARCH QUESTION}

To what extent does planning affect the performance of county governments in Kenya?

\section{LITERATURE REVIEW}

This study focused on Resource Based-View. Resource Based-View Theory (RBV) emerged in 1980s and 1990s, after the major works published by Barney and others on the Firm resources and sustained competitive advantage. It is argued by the supporters of this view that instead of the organizations looking competitive advantage from the external environment, they should look for them inside the company (Barney, (1). Despite the fact the RBV theory emerged in the early 1980s, it was progressively more visible in the 1990s. The RBV stressed out on the internal capabilities of an organization $(2,9,21,29)$. The foundation concept of the RBV is that no two organizations are the same because no two organizations have obtained the same position of organizational resources such as skills, capabilities, organizational culture and experiences (8). Thus, organizations must therefore own organizational resources with 
characteristics that are uncommon, precious, valuable to imitable, and that cannot be substituted. This allows them to hold the potential of continued viable advantage over other competitors (2).

Resource Based-View Theory is a widely used theory of strategic management that examines how resources can drive competitive advantage. Competitive advantage is the ability to create more value than competitors, and therefore generate higher returns on investment. Sustainable competitive advantage requires enduring benefits through capabilities that are not easily imitated (13). The theory basically stresses the idea that an organization must be taken as a bundle of resources and capabilities to create value and hence gain competitive advantage (2). The concept of resources includes all assets, capabilities, organizational processes, organization aspects, information and knowledge controlled by an organization that enable the organization to conceive and implement strategies that improve its efficiency and effectiveness. This means that the starting point of the analysis is the internal environment of the organization.

Literature revealed expressed that Resource Based-View and the core competencies of any organization have their own limitations. The RBV principally focus on the internal characteristics of organizations $(4,5,21)$ argue that RBV does not provide a holistic perspective for understanding how resources can be put into practice to create value for organizations. This is a limitation of the theory. As a theory of core competence, it views that the value of the brilliant people is more precious because it is component of an organizational system (16). In view of that, the significance of non-human characteristic of an organization, such as information communication technology (ICT), is often unnoticed. The strategic management process in public sector is more difficult (7) as an end result of the extraordinary characteristics of the organizations such as the amalgamation of volunteers and paid staff as well as responsibility of various sections of the government (25). Thus the theory of RBV for the purpose of acquiring core competence stress on the internal capabilities may not be able to provide an unbiased picture of how a public sector is performing. To overcome this limitation, knowledge management theory may be applied (30). In relation to this study, Resource-basedview theory is relevant as it brings out the initiatives and priorities that should be pursued by the county governments to enhance on their performance. Based on the RBV theory, it is, therefore, hypothesized that planning should improve the performance of county governments in Kenya.

Performance refers to the accomplishment of a given task measured against present known standards of accuracy, completeness, cost, and speed. In a contract, performance is deemed to be the fulfilment of an obligation, in a manner that releases the performer from all liabilities under the contract (12). Performance in the public sector has some general features which are accomplished in a performance measurement system that involves a relationship between inputs, process, outputs and outcomes which are then guided by two objectives that answers two questions: are we doing things right and are we doing the right things. The performance measurement system allows implementing some important actions and making some decisions based on quantifying the efficiency and effectiveness of past actions using appropriate information structure (18).

\section{CONCEPTUAL FRAMEWORK}

The literature review revealed that strategic planning is a widespread and popular practice in both the public and private sectors. Planning is a way of overseeing the formulation and implementation of strategy. It is systematic in nature and denotes to reinforce processes to produce the data and analyses used as inputs for strategic thinking, which combines the data 
contracts and county emphasizes assessment of citizens needs and expectations. A five point likert scale ranging from one (Strongly agree) to five (Strongly disagree) was used. The Cronbach's alpha coefficient value for performance was 0.78 and this indicate that the internal reliability of the scale was satisfactory.

\section{Descriptive Analysis for Governance}

\section{RESEARCH FINDINGS AND DISCUSSIONS}

Planning was measured by Mission Statement, Vision Statement, Core Values and Budget. The respondents were asked to indicate whether the current mission statement is compatible with the activities being carried out by the county government. The majority of the respondents indicated that their mission statement is compatible with the activities being carried on by the county government as represented by a valid percentage of $88.2 \%$ while the remaining $11.8 \%$ reported that their mission statement is not compatible with the activities carried on by the county government. This is an indication that most counties are able to plan because they have mission statement. Ninety three percent of the respondents agreed that the county government uses different strategies for generating resources, while $7 \%$ reported that the county government do not use different strategies. This outlines that different strategies are used by county governments to generate resources. When asked to state if the vision statement is relevant to the county's activities and mandate, 90.6\% responded that the vision statement is relevant to the county's activities and mandate while $9.4 \%$ of the respondents reported that the vision statement is not relevant to the county's activities and mandate. This gives a clear picture that vision statement is a very important drive in the county government activities and mandate.

The study revealed that county government vision statement is aspiring, inspiring and motivating as represented by a valid percent of $83 \%$. However, $17 \%$ disagreed with the statement. This gives an indication that the county governments' vision statement is about the goals of the counties as well as provide life and direction to the counties' day-to-day work and provides a reason for the work the counties does. The study sought to establish whether managers of the counties understand the counties' core values. While $67.9 \%$ of the respondents indicated that managers of the counties understand the counties' core values, $42.1 \%$ of the respondents were for the opinion that the managers of the counties do not understand the counties' core value. This gives a perception that county managers will need more training on the core values of the county governments.

Further, the study sought to establish if the county governments embraces core values to ensure that the desired destination in growth and development is achieved. The majority of the respondents indicated that they embrace core values to ensure that the desired destination in growth and development is achieved as represented by a valid percent of $73 \%$ while the remaining $27 \%$ indicated that the county governments do not embrace core values. The results establish that most counties are guided well by the core value in their planning. The study findings revealed that $70.7 \%$ either agreed or strongly agreed their counties are committed to providing financial resources to support the implementation of the county strategic initiatives while $29.3 \%$ of the respondents disagreed that their counties are committed to providing financial resources to support the implementation of the county strategy. This is an indication that counties provide financial resources to support in strategic planning. While $76.5 \%$ of the respondents outlined that the county governments ensured that budget reflects the priorities established in the strategic plans, $23.5 \%$ of the respondents reported that county government budgets do not reflect the priorities established in the strategic plans. The findings therefore reflect that county governments honour priorities established in their strategic plans. The study revealed that, the county governments make use of the budget to ensure that there are 
controls in the projects undertaken by the county. This is supported by the $79.7 \%$ of the respondents who either agreed or strongly agreed against $21.3 \%$ of the respondents who disagreed.

Table 1: Descriptive Statistics for Planning

\begin{tabular}{|c|c|c|c|c|c|c|c|c|c|}
\hline & \multirow{2}{*}{$\begin{array}{c}\text { St.D } \\
\%\end{array}$} & \multirow{2}{*}{$\begin{array}{c}\text { Sl.D } \\
\%\end{array}$} & \multirow{2}{*}{$\begin{array}{l}\mathrm{D} \\
\%\end{array}$} & \multirow{2}{*}{$\begin{array}{l}\mathrm{A} \\
\%\end{array}$} & \multirow{2}{*}{$\begin{array}{c}\text { St.A } \\
\%\end{array}$} & \multicolumn{4}{|c|}{ summary } \\
\hline & & & & & & $\mathrm{Mn}$ & $\mathrm{Md}$ & Mo & S.D \\
\hline $\begin{array}{l}\text { Mission statement is compatible with } \\
\text { activities }\end{array}$ & $1.6 \%$ & $2.3 \%$ & $7.8 \%$ & $64.8 \%$ & $23.4 \%$ & 4 & 4 & 4 & 1 \\
\hline $\begin{array}{l}\text { County uses different strategies to } \\
\text { generate resources }\end{array}$ & $0.0 \%$ & $2.3 \%$ & $4.7 \%$ & $76.6 \%$ & $16.4 \%$ & 4 & 4 & 4 & 1 \\
\hline $\begin{array}{l}\text { Vision Statement is Relevant to } \\
\text { County activities }\end{array}$ & $0.0 \%$ & $2.3 \%$ & $7.0 \%$ & $74.2 \%$ & $16.4 \%$ & 4 & 4 & 4 & 1 \\
\hline $\begin{array}{l}\text { Vision Statement is Aspiring, } \\
\text { Inspiring and Motivating }\end{array}$ & $0.0 \%$ & $10.2 \%$ & $7.0 \%$ & $74.2 \%$ & $8.6 \%$ & 4 & 4 & 4 & 1 \\
\hline $\begin{array}{l}\text { Managers understand county's core } \\
\text { values }\end{array}$ & $0.0 \%$ & $24.2 \%$ & $10.9 \%$ & $46.9 \%$ & $18.0 \%$ & 4 & 4 & 4 & 1 \\
\hline $\begin{array}{l}\text { County government embrace core } \\
\text { values }\end{array}$ & $0.8 \%$ & $14.1 \%$ & $11.7 \%$ & $67.2 \%$ & $6.2 \%$ & 4 & 4 & 4 & 1 \\
\hline $\begin{array}{l}\text { County government is committed to } \\
\text { providing financial resources to } \\
\text { support strategic initiatives }\end{array}$ & $0.0 \%$ & $4.7 \%$ & $25.0 \%$ & $62.5 \%$ & $7.8 \%$ & 4 & 4 & 4 & 1 \\
\hline $\begin{array}{l}\text { County government ensure budget } \\
\text { reflects strategic priorities }\end{array}$ & $0.0 \%$ & $6.2 \%$ & $17.2 \%$ & $69.5 \%$ & $7.0 \%$ & 4 & 4 & 4 & 1 \\
\hline $\begin{array}{l}\text { County government uses budget to } \\
\text { ensure controls in projects }\end{array}$ & $0.0 \%$ & $0.8 \%$ & $19.5 \%$ & $71.9 \%$ & $7.8 \%$ & 4 & 4 & 4 & 1 \\
\hline
\end{tabular}

$\mathrm{n}=128$

St.D=Strongly Disagree. Sl.D=Slightly Disagree, D=Disagree, A=Agree, St.A= Strongly Agree, $M n=$ Mean, Md=Median, Mo=Mode, S.D=Standard Deviation

Several factors were used to measure performance of County Governments in the study. The study findings showed that $81.2 \%$ of the respondents reported that their counties emphasized on assessment of citizen needs and expectations, whereas $18.8 \%$ reported that counties did not have any emphasize on assessment of citizen needs and expectations. This is an indication that needs and expectations of citizens in most counties were considered and met. Second, $51.6 \%$ of the respondents reported that the County cake is shared among all county residents, while $48.4 \%$ reported that the county cake is not shared among all county residents. The findings are an indication that the county government management should improve on sharing of county cake among citizens in their respective counties. Sixty Five point Seven percent $(65.7 \%)$ reported that employee satisfaction, via involvement and empowerment lead to efficiency in internal processes as while $34.3 \%$ of the respondents disagreed with the statement. These results show that employees in most counties were involved and empowered in running of the county governments. When asked whether good communication process ensure internal processes run smoothly, $75 \%$ of the respondents agreed with the statement while $25 \%$ of the respondents disagreed with the statement a prove that good communication resulted to improved performance. Further, the respondents were asked if county arrangements ensured inclusion and fairness, 53.9\% of the respondents reported that the arrangements included stakeholders and were fair while $46.3 \%$ reported non-inclusion and unfair. These results posed a platform where the county governments should improve on inclusion and fairness in their operation management to improve on performance of county governments.

When asked if county governments pursued efficient public procurement practices to ensure sound management of expenditure, majority of the respondents (65.7\%) agreed to the 
statement while $34.3 \%$ disagreed with the statement. The results show that most counties applied effective public procurement practices that ensured sound management of expenditure and this led to improvement in performance. The researcher further asked the respondents whether the suppliers are satisfied with quality and level of information in county government contracts and 55.5\% reported that they were while $44.5 \%$ disagreed with the statement. The results communicate that county governments should consider improving the quality and level of information in county government contracts.

Table 2: Descriptive analysis for County Government Performance

\begin{tabular}{|c|c|c|c|c|c|c|c|c|c|}
\hline & \multirow{2}{*}{$\begin{array}{c}\text { St.D } \\
\%\end{array}$} & \multirow{2}{*}{$\begin{array}{c}\text { Sl.D } \\
\%\end{array}$} & \multirow{2}{*}{$\begin{array}{l}\mathrm{D} \\
\%\end{array}$} & \multirow{2}{*}{$\begin{array}{l}\mathrm{A} \\
\%\end{array}$} & \multirow{2}{*}{$\begin{array}{c}\text { St.A } \\
\%\end{array}$} & \multicolumn{4}{|c|}{ Summary } \\
\hline & & & & & & Mn & $\mathrm{Md}$ & Mo & S.D \\
\hline $\begin{array}{l}\text { County emphasizes assessment of citizen } \\
\text { needs and expectations }\end{array}$ & $0.0 \%$ & $7.8 \%$ & $10.9 \%$ & $78.1 \%$ & $3.1 \%$ & 4 & 4 & 4 & 1 \\
\hline $\begin{array}{l}\text { County cake is shared among all county } \\
\text { residents }\end{array}$ & $6.2 \%$ & $23.4 \%$ & $18.8 \%$ & $47.7 \%$ & $3.9 \%$ & 3 & 4 & 4 & 1 \\
\hline $\begin{array}{l}\text { Employee satisfaction, via involvement and } \\
\text { empowerment, lead to efficiency in internal } \\
\text { processes }\end{array}$ & $0.8 \%$ & $22.7 \%$ & $10.9 \%$ & $64.1 \%$ & $1.6 \%$ & 3 & 4 & 4 & 1 \\
\hline $\begin{array}{l}\text { Good communication process ensure } \\
\text { internal processes run smoothly }\end{array}$ & $0.0 \%$ & $11.7 \%$ & $13.3 \%$ & $67.2 \%$ & $7.8 \%$ & 4 & 4 & 4 & 1 \\
\hline New opportunities benefit all stakeholders & $4.7 \%$ & $26.6 \%$ & $25.0 \%$ & $42.2 \%$ & $1.6 \%$ & 3 & 3 & 4 & 1 \\
\hline $\begin{array}{l}\text { County arrangements ensure inclusion and } \\
\text { fairness }\end{array}$ & $5.5 \%$ & $19.5 \%$ & $21.1 \%$ & $51.6 \%$ & $2.3 \%$ & 3 & 4 & 4 & 1 \\
\hline $\begin{array}{l}\text { Efficient public procurement practices are } \\
\text { pursued to ensure sound management of } \\
\text { expenditure }\end{array}$ & $2.3 \%$ & $10.2 \%$ & $21.9 \%$ & $64.1 \%$ & $1.6 \%$ & 4 & 4 & 4 & 1 \\
\hline $\begin{array}{l}\text { Suppliers are satisfied with quality and level } \\
\text { of information in contracts }\end{array}$ & $0.8 \%$ & $20.3 \%$ & $23.4 \%$ & $53.9 \%$ & $1.6 \%$ & 3 & 4 & 4 & 1 \\
\hline County relates well with all stakeholders & $0.0 \%$ & $21.1 \%$ & $31.2 \%$ & $43.8 \%$ & $3.9 \%$ & 3 & 3 & 4 & 1 \\
\hline
\end{tabular}
$\mathrm{n}=128$

St.D=Strongly Disagree. Sl.D=Slightly Disagree, D=Disagree, A=Agree, St.A= Strongly Agree, $M n=$ Mean, Md=Median, Mo=Mode, S.D=Standard Deviation

\section{Correlation Analysis}

Performance had a positive and significant correlation with planning $(\mathrm{r}=0.330$, $\mathrm{p}$-value < 0.000). This means, an increase in planning leads to an increase in county government performance.

Table 3: Correlations Analysis

\begin{tabular}{lccc}
\hline & $\mathrm{X}$ & $\mathrm{Y}$ \\
\hline Planning & Correlation & 1 & $330^{* *}$ \\
\hline Sig. (2-tailed) & & 0.000 \\
$\mathrm{~N}$ & 1 & 128 \\
\hline **. Correlation is significant at the 0.01 level (2-tailed). & & \\
$*$. Correlation is significant at the 0.05 level (2-tailed). & & \\
\hline
\end{tabular}

Key: Y=County Government Performance

$\mathrm{X}=$ Planning

\section{Regression Analysis}

Ho1: There is no significant relationship between Governance and the Performance of County Governments in Kenya 


\section{Planning and County government performance Model Summary}

The coefficient of determination ( $\mathrm{R}$ squared) of 0.109 indicates that $10.9 \%$ of county government performance can be explained by planning. The adjusted $\mathrm{R}$ square of $10.2 \%$ explains that planning in the exclusion of the constant variable explain there is no change in county government performance. The remaining percentage can be explained by other factors not included in the model. The $\mathrm{R}$ indicates the correlation coefficient of the effects of planning, an $R=0.330$ shows that there is a positive relationship between planning and county government performance. The standard error of estimate (0.50) shows the average deviation of the independent variables from the line of goodness fit.

Table 4: Planning and County government performance Model Summary

\begin{tabular}{ccccc}
\hline Model & $\mathrm{R}$ & $\mathrm{R}$ Square & Adjusted R Square & Std. Error of the Estimate \\
\hline 1 & $.330^{\mathrm{a}}$ & .109 & .102 & .50221 \\
\hline
\end{tabular}

a. Predictors: (Constant), PLANNING

\section{Planning and County Government Performance}

The F statistics was used to test for the model goodness of fit. Table $5(\mathrm{~F}=15.350, \mathrm{p}$ value $=$ 0.000 ) indicates that there is a significant relationship between planning and county government performance and at least the slope ( $\beta$ coefficient) is not zero.

Table 5: Planning and County Government Performance ANOVAa

$\begin{array}{lccccc}\text { Model } & \text { Sum of Squares } & \text { df } & \text { Mean Square } & \text { F } & \text { Sig. } \\ \text { Regression } & 3.871 & 1 & 3.871 & 15.350 & .000^{\mathrm{b}} \\ \text { Residual } & 31.780 & 126 & .252 & & \\ \text { Total } & 35.651 & 127 & & & \end{array}$

a. Dependent Variable: PERFORMANCE

b. Predictors: (Constant), PLANNING

\section{Planning and County Government Performance Regression Weights}

The study hypothesized that planning does not affect the performance of county governments in Kenya. The study findings showed that there was a positive and significant relationship between planning and county government performance $((\beta=0.411, p$-value $=0.000<0.05)$. This means that a unit increase in planning leads to an increase in county government performance by 0.411 . Since the $\mathrm{p}$ value was less than 0.05 , the null hypothesis was rejected and the alternative hypothesis was accepted. The study therefore concluded that planning has a significant influence on performance of county governments in Kenya.

Table 6: Planning and County Government Performance Regression Weights

\begin{tabular}{llccccc}
\hline \multirow{2}{*}{ Model } & & \multicolumn{2}{c}{ Unstandardized Coefficients } & Standardized Coefficients & t & Sig. \\
& & $\mathrm{B}$ & Std. Error & Beta & & \\
\hline \multirow{2}{*}{1} & (Constant) & 1.826 & .405 & & 4.506 & .000 \\
& PLANNING & .411 & .105 & .330 & 3.918 & .000 \\
\hline
\end{tabular}

a. Dependent Variable: PERFORMANCE

\section{DISCUSSION}

The findings of the study greatly contradicts the hypothesis that planning does not affect the performance of county governments in Kenya. The results of the regression analysis indicates that planning has significant effect on performance of county governments in Kenya. Planning was second compared to other variables and this is an implication that good performance by 
county governments is highly influenced by effective planning. Similar conclusions were drawn by Gichunge (11), Rothaermel (22) and Theodore (26).

\section{SUMMARY AND CONCLUSION}

The objective of this paper was to investigate the effect of planning on the performance of county governments in Kenya. It was established that through planning, the county governments have found a footing in terms of implementing the county integrated development plans. As such concerted planning efforts were necessary to improve county government performance. Based on the results of this study, it is concluded that planning as used by county governments is positive significant factor in relation to county government performance.

\section{RECOMMENDATIONS}

From the findings of the study, it is recommended that the county governments should emphasize on implementing the county integrated development plans. In planning, duly clarified roles and responsibilities will ensure less duplication of duties and accountability which will help the counties in reducing wastage of resources meant for the implementation process. The study therefore recommends further improvement in planning to harness the benefits accrued from planning. While the objective of the study was successfully met, it is recommended that future research on planning may be conducted in other state bureaucracies that have better policies and practices than county governments.

\section{References}

Barney, J. B. (1991). Firm Resources and Sustained Competitive Advantage. Journal of Management, 17(1), 99120.

Barney, J. B. (2001). Is the resource-based view a useful perspective for strategic management research? Yes. Academy of Management Review, 26(1), 41-56.

Barney, J. B. (2001). Firm Resources and Sustained Competitive Advantage. Journal of Management, 17(1), 99-120.

Bontis, N. (2002). Managing organizational knowledge by diagnosing intellectual capital: Framing and advancing the state of the field on the strategic management of intellectual capital and organizational knowledge. Strategic Management Journal, 10(3), 621-42.

Bontis, N. (1999), Managing organizational knowledge by diagnosing intellectual capital: Framing and advancing the state of the field. International Journal of Technology Management, 18(8), 433-62.

Bryson, J.M. (2011). A strategic Planning Process for Public and Non-Profit Organizations, Long Range Planning Journal, 25(1), 107-116.

(Chetkovich, C. \& Frumkin, P. (2003) Balancing Margin and Mission. Strategic Management Journal, 35(5), 564596.

Collis, D. \& Montgomery, J. (1995). A resource-based analysis of global competition: The case of the bearings industry, Strategic Management Journal, 12(1), 49-68.

Conner, K. (2002). An historical comparison of resource-based logic and five schools of thought within industrial organization economics: Do we have a new theory of the firm here? Journal of Management, 17(2), $121-154$.

Cronbach, L. J. (2004). My current thoughts on coefficient alpha and successor procedures. Educational and Psychological Measurement Journal, 64(1), 391-418.

Gichunge, E. M. (2007). The Effect of Formal Strategic management on Organizational Performance. Unpublished PhD Dissertation, University of Nairobi, Kenya.

Grafton, J., Lillis, A. M., \& Widener, S. K. (2010). The role of performance measurement and evaluation in building organizational capabilities and performance. Accounting, Organizations and Society Journal, 35(7), $689-706$.

Killen, C., Jugdev, K., Drouin, N. \& Petit, Y. (2012). Advancing project and portfolio management research: Applying strategic management theories. International Journal of Project Management, 30(5), 525-538. 
Korir, V. C. (2013). Challenges affecting devolution of Public Sector in Local Authorities in Kenya, a Case of County Government of Kericho, Unpublished MBA project, Kenyatta University, Nairobi, Kenya.

Mintzberg, H. (2008). Reflecting on the strategy process. Sloan Management Review, 40(1), 21-30.

Molina-Azorín J.F. (2014). Micro-foundations of strategic management: toward micro-macro research in the resource-based theory. Business Research Quarterly Report, 17(2), 20-24.

Muli, J. N. (2014). The Challenges of Implementation of Devolution Strategy at the Nairobi County Government in Kenya. Unpublished MBA project, University of Nairobi, Kenya.

Neely, A., Adams C., \&Kennerly, M. (2007). The Performance Prism. The Scorecard for Measuring and Managing Business Success. Glouster, UK: Financial Times, Prentice Hall

Nickols F. (2016). Strategy, Strategic Management, Strategic Planning and Strategic Thinking. Management Journal, 1(1), 4-7.

Ondigi C. N., (2014) Challenges Facing Devolution in Kenya: A Comparative Study. Nairobi, Kenya.

Peteraf, Margaret A. (1993). The Cornerstones of Competitive Advantage: A Resource Based View. Strategic Management Journal. 14(2), 179-191.

Rothaermel, F. T. (2012). Strategic Management: Concepts and Cases. Homewood, IL: Irwin.

Schiuma, G., A. Lerro, and D. Carlucci (2005). An Inter-firm perspective on intellectual capital. Perspectives in intellectual capital Review. 13(4), 155-169.

Smith, R. J. (2005). Strategic Management and Planning in the Public Sector. London. Longman.

Sveiby, K. E. (2001). A knowledge-based theory of the firm to guide in strategy formulation. Journal of Intellectual Capital, 2(4), 345-365.

Theodore, H. P. (2010). The Future of Strategic Planning in the Public Sector: Linking Strategic Management and Performance. Journal on Strategic Management, 70(1), 246-254.

Thompson, J., \& Strickland, A.J. (2003). Strategic Management: Concepts and Cases. Homewood, IL: Irwin.

Tsang, K., K. (2012). The use of midpoint on Likert Scale: The implications for Educational Research. Hong Kong Teachers Centre Journal, 11(1), 121-130.

Wernerfelt, Birger (1984). A Resource-based View of the Firm. Strategic Management Journal, 5(3), 171-180.

Zack M. H. (2005). The strategic advantage of knowledge and learning. International Journal of Learning and Intellectual Capital, 2 (1), 1-20. 